\title{
COMMUNICATIONS
}

Editor, Journal of Asian Studies:

Pearl S. Buck's The Living Reed is an excellent historical novel on modern Korea that I for one would encourage students taking courses in East Asian history to read. It well deserves the attention given it by a review appearing in this journal (XXXIII [May, I964], $4^{8 \mathrm{rf}) .}$

Despite its general excellence, the work has a weakness from the viewpoint of the historian. Miss Buck emphasizes in the novel that Washington was callous and unconcerned about the threat of Japan to the independence of Korea at the turn of the twentieth century, even though some Koreans were looking to the United States as their sole friend among the European powers. Along this line it is stated (and repeated in the review of the book cited above) that, through the "secret Taft-Katsura Agreement" of July, I905, President Theodore Roosevelt endorsed Japan's control of Korea in return for Japan's promise not to attack the Philippines (p. 477). This interpretation is no longer tenable.

It is true that President Roosevelt thought that Japan was entitled to rule Korea as a fruit of Japan's victory over Russia and that Japan's absorption in the task of developing Korea and southern Manchuria would, for some time to come, keep her from harboring designs on the Philippines (Theodore Roosevelt, The Letters of Theodore Roosevelt, ed. Elting E. Morison, et. al. [Cambridge, Mass., I95I-54], IV, 83If, I233). But, it is not true that by means of that "secret pact" he sacrificed Korea in order to protect the Philippines. Professor Raymond A. Esthus has shown that the "agreement" was merely an agreed memorandum and no secret bargain or quid pro quo in the nature of a guarantee for the Philippines. Twice before the Taft-Katsura conversation President Roosevelt gave his blessing to Japan's free hand in Korea. In February, I905, he undertook to inform Japan through unofficial channels that she had the complete support of the United States in her takeover of Korea and the Liaotung Peninsula. Two months later, he personally told the Japa- nese Minister Takahira Kogorō that he approved of the control of Korea by Japan. In both instances nothing was asked of Japan by Roosevelt in return for his assurances (Raymond A. Esthus, "The Taft-Katsura Agreement-Reality or Myth?" Journal of Modern History, XXXI [March, 1959], 46-51).

What then explains President Roosevelt's endorsement of the mastery of Korea by Japan? One reason was that he had no respect for the Koreans. To Roosevelt, valuing rugged, manly, personal virtues as he did, they were effete; they could not even "strike one blow" against Japan in their defense. Moreover, they were incapable of self-government, a hallmark of the "civilized." Another reason is related to his deep-seated belief in the mission of the "civilized" toward the "backward." In the years 1904-05 he believed that Japan, whom he regarded as the only civilized nation in Asia, should police the Yellow Sea just as the United States was policing the Caribbean (Letters, IV, III2, III6, 830). This more than any other factor explains why he appeared heartless toward the Koreans when Japan's take-over of Korea seemed assured in early r905.

Richard T. Chang

\section{University of Kansas}

\section{Editor, Journal of Asian Studies:}

The misunderstanding, by your reviewer, of Professor Tinker's India and Pakistan: $A$ Political Analysis, evident in the review printed in the Journal (Nov., 1963) does not seem to have been cleared up by subsequent correspondence. Mr. T. V. Sathyamurthy, in reply to my criticism of his review, remains convinced that Professor Tinker "has relied heavily on Western concepts of democracy as normsespecially the nineteenth-century liberal conception of democracy." One of the examples from the book which Mr. Sathyamurthy now offers, in his reply, suggests the gross misreading of Professor Tinker's analysis which characterizes the reviewer's assessment:

“... on page 20r, he (Professor Tinker) expresses the view that 'should another major step be taken 
away from an electoral system based on 'one man, one vote,' towards a 'communitarian society,' it will mean abandoning one of the fundamental features of Western liberal democracyl..." In fact, the text (p. 20I) reads:

"Should another major step be taken away from an electoral system based on 'one man, one vote' towards a 'communitarian society', this will indicate a real shift in political values. It may be that the latter will prove more democratic, in the context of South Asia; but it will mean abandoning one of the fundamental features of Western liberal democracy; the belief in the autonomy of the individual."

It is regrettable that $\mathrm{Mr}$. Sathyamurthy chose to delete (without indication) parts of this passage, for the deletions create a distorted version of Professor Tinker's argument.

A careful reading of this passage, within its larger context, shows that Professor Tinker is concerned with the particular demands, prop- erties, and characteristics of democracy "in the context of South Asia." He sees the "communitarian society," advocated by Jayaprakash Narayan, as the most suitable social order for this South Asian context. He does not feel that "one of the fundamental features of Western liberal democracy, the belief in the autonomy of the individual," is appropriate to this context, and thus he in no sense advocates it as a "norm." Professor Tinker's dominant concern is with the evolution of an Asian brand of democracy, to which many values of the Western conception are notably inapplicable. A serious and fair reading of this book, which is as well-written as it is well-argued, sets forth these points, however, far better than is possible in this short space.

\section{School of Oriental and}

African Studies 